\title{
GLOSA W KWESTII UKRAINA MIĘDZY WSCHODEM A ZACHODEM
}

\author{
Stefan Kozak \\ Uniwersytet Warszawski, Professor Emeritus \\ Warszawa, Polska \\ ORCID: 0000-0002-4621-8780
}

\section{A REMARK ON THE ISSUE OF UKRAINE PLACED BETWEEN EAST AND WEST}

\begin{abstract}
The departure point of the article is the well-known and almost obvious point about Ukraine placed between the Byzantine East and Latin-European West and its multifaceted justification: geographical, political, historical, religious, cultural, with each of these aspects closely bound with one another. What follows is a synthetic overview of historical and cultural facts, Ukrainian political writings, works of literature, as well as anonymous Cossack songs and dumkas, stressing the presence of Occidentalist thought permeating them, which testifies to the conscious reception and development of modern European thought, political, liberal and democratic, by Ukrainian thinkers, who harmoniously blended it with Christian values, which were of paramount importance to their thinking. The objective of the present synthesis is to characterise the pro-Western current, its origins and development since the time of Ukraine's submission to Russia (after the Pereyaslav Council) and, ultimately, its role in the resistance movement against the imperial, absolutist and Russificating policy of the Romanov dynasty, and in the shaping of the national consciousness the Ukrainians and their struggle for independence.
\end{abstract}

Key words: Ukraine, Byzantine East, Latin-European West, Occidentalism, liberating tendencies

„Ukraina między Wschodem a Zachodem” to częsty motyw w ukazujących się ostatnio publikacjach poświęconych Ukrainie, w szczególności jej tożsamości narodowej i europejskiej. Kierunki poszukiwań są wielorakie, skupiają się one najczęściej na relacjach Ruś - Bizancjum - Rzym lub uwarunkowaniach, następstwach i kontekście Włodzimierzowego chrztu Rusi-Ukrainy przyjętego z Bizancjum, bądź na przestrzeni geograficzno-religijnej i ówczesnej sytuacji historyczno-politycznej, bądź także na dziejach literatury i kultury ukraińskiej, ukształtowanej właśnie na fundamencie kultury i cywili- 
zacji bizantyjsko-rzymskim, śródziemnomorskim ${ }^{1}$. Można więc powiedzieć, iż Ruś Kijowska łączyła w sobie grecko-bizantyjską tradycję religijno-kulturową $\mathrm{z}$ europejskimi wpływami, w tym strukturami społecznymi i politycznymi.

Oczywista, sprzyjały temu również różne czynniki, procesy i wydarzenia, by wspomnieć dla przykładu małżeństwa członków dynastii kijowskiej z partnerami z Polski, Francji, Niemiec, Skandynawii; nie przypadkiem więc, że księcia Jarosława Mądrego ukraińscy historycy nazywają wręcz „teściem Europy" (swoje córki powydawał za książąt i królów państw europejskich). Tak oto średniowieczna Ruś-Ukraina nawiązywała bezpośrednie kontakty z Europą, otwierając się jednocześnie na jej różnorakie wpływy.

Badając wpływy greckie i łacińskie w ukraińskiej kulturze, profesor Ihor Szewczenko, jeden z najwybitniejszych współczesnych bizantynistów (nota bene doktor honoris causa Uniwersytetu Warszawskiego i Katolickiego Uniwersytetu Lubelskiego Jana Pawła II) w swoim interesującym eseju Ukraina między Wschodem a Zachodem trafnie zauważa, iż „Bizancjum - czy też, jeśli ktoś woli, Konstantynopol - leży nie na wschód, lecz na południe, a nawet południowy zachód od Kijowa. Wynika z tego, że w przypadku Bizancjum powinniśmy mówić o wpływie wywieranym na Ukrainę nie przez Wschód, lecz przez część cywilizacji śródziemnomorskiej. Mimo to czujemy instynktownie, że Wschód oznacza Bizancjum, a Zachód oznacza Europę"2.

To przewodni motyw cytowanej pracy uczonego; wiele wątków owej opozycji „Wschód-Zachód”, ciągłości i zmienności wpływów helleńsko-łacińskich, występujących w różnych okresach historycznych i kulturowych dziejów Ukrainy lub sąsiedzkiego, zwłaszcza polskiego pośrednictwa na Ukrainie, wejdzie do podstawowego kanonu pytań i lektur tytułowego zagadnienia. Warto przypomnieć, że niektóre rozdziały owej książki Ihora Szewczenki ukazały się jako trzeci tom znakomitej serii wydawniczej Ośrodka Badań nad Tradycją Antyczną w Polsce i w Europie Środkowo-Wschodniej Uniwersytetu Warszawskiego pt. Ukraina miedzy Wschodem a Zachodem³. Godzi się podkreślić, iż interesującą serię tego Ośrodka zapoczątkowały takie publikacje, jak Tradycje antyczne $w$ kulturze europejskiej - perspektywa polska ${ }^{4}$ oraz Łacina w Polsce. Konteksty: między Slavia Latina i Slavia Orthodoxa ${ }^{5}$.

\footnotetext{
Zob. np. N. Davies, Europa między Wschodem a Zachodem, Kraków 2007 oraz I. Шевченко, Украйна між Сходом і Заходом, Львів 2001; A. Wilson, Ukraińcy, Warszawa 2002.

2 I. Шевченко, op.cit., s. 1-2. Szeroki kontekst tego problemu prezentują w cytowanych pracach Norman Davies oraz Andrew Wilson.

3 I. Ševčenko, Ukraina między Wschodem a Zachodem. Warszawa 1996. Jest to przekład esejów dokonany $\mathrm{z}$ angielskiego oryginału.

4 Tradycje antyczne w kulturze europejskiej-perspektywa polska, oprac. i red. A. Rabińska, Warszawa 1995.

5 Lacina w Polsce. Konteksty: między Slavia Latina i Slavia Orthodoxa, red. E. J. Głębicka, J. Axer, Warszawa 1995.
} 
W kontekście tytułowego ujęcia zwraca na siebie uwagę otwierający tom szkic wybitnego włoskiego slawisty Riccarda Picchiego, zatytułowany Latinitas Slaviae Romanae; jego ideą jest wyjście poza spór między Slavia Latina i Slavia Orthodoxa, zaś wyraźnym postulatem jest potraktowanie łacińskości Słowiańszczyzny jako zjawiska porównywalnego z łacińskością europejskiej wspólnoty zachodniej tradycji rzymskiej. Oczywista, jest to teza miła uchu Słowianina, ale nieco przesadna, wszak każdy naród słowiański przyjmował humanistyczną tradycję łacińską $\mathrm{w}$ różnym czasie, $\mathrm{z}$ różną intensywnością i nasileniem; stąd też Riccardo Picchio wyprowadza wniosek, że ,znajomość kultury klasycznej na ziemiach ukraińskich rozpowszechniła się zwłaszcza w stuleciach XVI i XVII dzięki wzorom łacińsko-polskim. Nauczanie poetyki i retoryki przyczyniło się wtedy do upowszechnienia w kulturze ruskiej sposobu pojmowania pisarskiej twórczości skrajnie różnego od tego, który przez stulecia narzuciła doktryna kościelna Słowiańszczyzny prawosławnej. Zastąpienie klasyczno-humanistycznymi normami staroruskich paradygmatów pisarskich i doktrynalnych wywołało silny szok, którego skutki dość szybko z ziem ukraińskich sięgnęły państwa moskiewskiego"6.

Pozostając $\mathrm{w}$ zakreślonym tu kręgu myślowym należy podkreślić, iż przełomową rolę w europeizacji tożsamości kulturowej na Ukrainie odegrały dwie uczelnie - Akademia Ostrogska i Akademia Kijowsko-Mohylańska, wzorowane na szkołach jezuickich, które w okresie ponad 20 lat panowania hetmana Iwana Mazepy (wybitnego mecenasa kultury i sztuki, zdecydowanego okcydentalisty) przeżywały swój burzliwy rozwój i rozgłos w Europie. Godzi się przy tej okazji zaznaczyć, iż interesującą egzemplifikację wybranych zagadnień przedstawiły we wspomnianym zbiorze dwie badaczki: Natalia Jakowenko w artykule Niespodzianki ukraińskiej historii przedstawionej po tacinie $^{7}$ oraz Teresa Chyczewska-Hennel w syntetycznym szkicu Lacina na Zaporoż $u^{8}$. W obu tekstach przekonująco ukazano, jak naturalnym procesem było upowszechnianie się łaciny w ówczesnym piśmiennictwie ukraińskim, w szkołach, kancelariach hetmańskich, w korespondencji dyplomatycznej9. Przypomnijmy, Kozaczyzna odgrywała wówczas aktywną rolę na arenie międzynarodowej. I nie idzie tu tylko o konflikty i polityczno-wojskowe układy Kozaczyzny z Rzeczpospolitą, Moskwą, Półksiężycem, lecz także o relacje z państwami europejskimi, czego spektakularnym przykładem było zaproszenie Kozaków do ligi antytureckiej, montowanej przez Wenecję, Rzym

\footnotetext{
$6 \quad$ Lacina w Polsce. Konteksty: między Slavia Latina i Slavia Ortodoxa, Warszawa 1995, s. 11.

7 N. Jakowenko, Niespodzianki ukraińskiej historii przedstawionej po łacinie, [w:] Lacina w Polsce: Między Slavia latina a Slavia orthodoxa, red. J. Axer Warszawa 1995, s. 45-54.

8 T. Chynczewska-Hennel, Lacina na Zaporożu, [w:] Konteksty. Między Slavia Latina i Slavia Orthodoca, red. J. Axer, Warszawa 1995.

9 Lacina w Polsce. Konteksty: między Slavia Latina i Slavia Ortodoxa, Warszawa 1995, s. $45-59 ; 61-72$.
} 
i Wiedeń. To nie był przypadek, widać więc, iż w stolicach europejskich traktowano Kozacką Ukrainę jako „przedmurze chrześcijaństwa”. Sztukę walki z Półksiężycem Kozacy doprowadzili do perfekcji, czego dowodzili w licznych wyprawach morskich oraz bitwach i wojnach z Turcją, by wspomnieć chociażby o udziale Kozaków w słynnej wiktorii wiedeńskiej.

Wspomniana tu rola Ukrainy jako ,przedmurza chrześcijaństwa” jest zapewne chwalebna i zaszczytna, ale czy pamięta o niej Europa, czy pozostaje ona w pamięci potomnych? Nie należy zapominać, iż to właśnie Ukraina, jej ludność, stawała się przez wiele wieków łupem i ofiarą wyniszczających napadów osmańskich grabieżców. Wolno sądzić, iż w świadomości europejskiej owa rola Ukrainy jako „przedmurza chrześcijaństwa”, jako państwa „buforowego", wreszcie jako państwa granicznego, położonego między Wschodem a Zachodem, jest raczej skromna.

Pomijając ówczesne diariusze i barwne opisy Ukrainy i Kozaczyzny, np. Ericha Lassoty i Guillaume'a de Beauplana, dzisiaj jednym z bardziej interesujących wyjątków może być cytowana książka Normana Daviesa oraz Andrew Wilsona praca pt. Ukraińcy, której autor sytuując powyższą kwestię w kontekście mitu chrześcijańskiej Ukrainy i genealogii Kozaków wyprowadzonej od Sarmatów Roksolańskich, swój wywód kończy konkluzją, że „roksolański sarmatyzm kozacki pozwolił przekroczyć granice słabo zdefiniowanego pojęcia Slavia Orthodoxa, wzbogacając kształt ich [Kozaków] tożsamości grupowej o wyraźne poczucie więzi z pewnym określonym geograficznie terytorium. Za wschodnią granicę kontynentu europejskiego uważano wówczas Don (wyznaczona jeszcze przez Ptolemeusza naturalna linia graniczna między Sarmacją Europejską i Azjatycką). Tym samym Kozacy zawłaszczyli dla siebie przestrzeń między wschodnią krawędzią świata katolickiego a tą rzeką (Donem), traktowaną skądinąd również jako antymurale Cristianitas. Ponowne odkrycie genetycznego związku z dawną Rusią (Kijowską) to w znacznej mierze dopiero dzieło dziewiętnastowiecznych historyków ukraińskich"10.

W związku z powyższą konkluzją należy podkreślić, iż jest to niepełny obraz sytuacji. Nie można wszakże zapominać, iż czołowi dziejopisarze kozaccy: Samowidziec, Hrabianka, Wełyczko, anonimowy autor Historii Rusów, wręcz świadomie nawiązywali do geopolitycznej koncepcji Rusi Kijowskiej, zwróconej zarówno ku Wschodowi, jak i Zachodowi, a także w sposób dramatyczny opisywali dzieje kozackiej misji antymurale Cristianitas, wzorując się na Liwiuszu i Tacycie oraz wkładając w usta historycznych postaci nader patriotyczne przemówienia ${ }^{11}$.

\footnotetext{
10 A. Wilson, Ukraińcy, op. cit., s. 64.

11 Ukazałem to na przykładzie Historii Rusów, zob. S. Kozak, U źródet romantyzmu i nowożytnej myśli społecznej na Ukrainie, Wrocław 1978 oraz tenże, Preromantyzm ukraiński, Warszawa 2003.
} 
Niesłusznie zatem pomija się w badaniach ten segment ukraińskiego piśmiennictwa epoki baroku (a także oświecenia i preromantyzmu), tak samo jak niesłusznie bagatelizuje się rolę i znaczenie eposu kozackiego - historycznych pieśni i dum - w kształtowaniu świadomości narodowej Ukraińców, w zachowaniu ciągłości historycznej i kulturowej narodu od czasów Powieści minionych lat i Słowa o pułku Igora do epoki nowożytnej, łącznie z dobą romantyzmu i współczesnością.

Upominając się o pamięć dla kozackiej epiki bohaterskiej (z której czerpali obficie dziejopisarze i pisarze) należy stwierdzić, że to właśnie w historycznych pieśniach i dumach, w najbardziej dramatycznej i ekspresyjnej formie, wyrażony jest sens owego ,przedmurza chrześcijaństwa”. Oto tytułem egzemplifikacji fragment dumy Ptacz niewolnika:

Тоді-то далася бідному невільнику туреиька неволя добре знати:

Кайдани руки і ноги заїдали,

Сирая сириця до жовтої кості біле тіло проїдала.

То бідні невільники на кров, на тіло поглядали,

Об вірі християнській гадали,

Землю турецьку, віру бусурманську

Кляли-проклинали:

[...]

„Ти земля турещька, ти віра бусурманська.

Ти розлука християнська:

А вже ж не одного ти розлучила

Мужа з жоною,

Брата з сестрою,

Діток маленьких з отием, маткою!”

Визволь, Боже, бідного невільника

На святоруський берег,

У край веселий,

У мир хрещений ${ }^{12}$.

Zacytowano tu fragment dumy Płacz niewolnika, który celnie i obrazowo oddaje przewodni motyw ukraińskich „,niewolniczych dum”: „za ziemię ojczystą" i „,wiarę chrześcijańską”. Budzi podziw heroiczna postawa Kozaków, ich model patriotycznego odczuwania, łączącego myślenie religijne $\mathrm{z}$ historycznym, ze świadomością, że walka z Półksiężycem, że owe męki w tureckich lochach i na galerach to świadectwo szerokiego uczestnictwa we wspólnocie losów historycznych „narodu chrzczonego”.

12 Думи, Упорядкував, вступ і коментарі написав Г. Нудьга, Київ 1969, s. 58-60 i in. 
Taka postawa umacnia wiarę w konieczność ofiarności dla wspólnoty, nie przypadkiem więc walki z wyznawcami „bisurmańskiej wiary” uaktywniły szerokie warstwy społeczne, wzbudziły ich poczucie przynależności religijnej i narodowej. Niestety, po Perejasławiu (1654 r.) losy hetmańskiej Kozaczyzny zostały przesądzone pod rządami Romanowów, zaś owe procesy i zjawiska uległy osłabieniu i wyhamowaniu, więcej - poddane ostrym restrykcjom; Ukraina bowiem zderzyła się w despotycznym azjatyckim Wschodem. Mimo to jednak likwidacyjne akty Piotra I, zwłaszcza zaś carycy Katarzyny, o rozwiązaniu ustroju hetmańskiego (1764 r.), likwidacji Siczy Zaporoskiej (1775 r.) oraz zaprowadzeniu poddaństwa (1783 r.) wzbudziły na Ukrainie, głównie wśród autonomistów, kozactwa, szlachty i ludzi z kręgu inteligencji, ostry sprzeciw, czego przykładem jest właśnie Historia Rusów oraz - by pozostać przy folklorze - historyczne pieśni odnoszące się do tych aktów:

Бодай наша иариия Катерина

На світі не жила,

Що степ добрий, край веселий

Тай занапастила!

Бодай наша Катерина

Та царства не мала,

Що наших хлопиів,

Славних запорожиів,

За Дунай загнала!

А которі осталися,

То в москалі взяла.

Бодай наша Катерина

На світі не жила,

Що ту землю нашу Запорозьку,

Зовсім розорила! ${ }^{13}$.

Tak oto lud Ukrainy ocenił „reformatorskie” poczynania „oświeconej imperatrycy”, która powołując się na „nowy duch czasów” w swoich aktach likwidacyjnych zarówno Hetmańszczyznę, jak i Sicz Zaporoską określiła jako organizmy anachroniczne, warcholskie, niezgodne $\mathrm{z}$,ideą oświeconej monarchii”. Warto w tym miejscu przypomnieć, iż analogiczną argumentację zastosowała owa „filozofka na tronie” (legitymująca się znajomością z Diderotem i Wolterem) w aktach dokonujących rozbioru Polski. Oczywiście, wespół z Austrią i Prusami.

I tak oto na oczach Europy i przy jej współudziale, Ukraina i Polska zostały włączone do imperium, wprzęgnięte w rydwan rosyjskiej, zaborczej polityki

13 Козацькі пісні, Київ 1969, s. 270-271. 
i wymazane na dhugie lata z mapy Europy. Oto kwintesencja dotychczas omawianego tu problemu - dylematu „Ukraina między Wschodem a Zachodem”.

Przypomnijmy, że działo się to w okresie, kiedy Ameryka ogłosiła Deklarację Niepodległości i Konstytucję, zaś Francję ogarnęła Wielka Rewolucja, której hasła: „Wolność, Równość i Braterstwo” odbiły się głośnym echem w całej Europie, zapoczątkowując tym samym nową epokę w jej nowożytnych dziejach.

W tym kontekście ukraiński wybór między Wschodem a Zachodem nie budził wątpliwości. Dostrzega się w tym okresie zdecydowaną reakcję Ukraińców na owe restrykcyjne akty carycy Katarzyny II. Dotyczy to przede wszystkim formowania się ruchu obywatelskiego w środowiskach autonomistów, bardzo wpływowych i prężnych, bądź to poprzez ruch wolnomularski, wszak loże masońskie powstawały wówczas na Ukrainie nawet w prowincjonalnych ośrodkach, by wspomnieć chociażby Połtawę, gdzie w loży „Miłość do Prawdy" wiodącą rolę odgrywał Iwan Kotlarewski, twórca nowoczesnego języka ukraińskiego i literatury.

A stało się to dzięki odwołaniu się kapitana Iwana Kotlarewskiego do dziedzictwa kultury łacińskiej, tj. do Eneidy Wergiliusza. Genialność Kotlarewskiego polega zatem na zespoleniu antycznych motywów treściowych z ukraińskimi, z kozacką epiką bohaterską i historią najnowszą. Otóż dostrzegł on analogię wędrówek Wergiliuszowego Eneasza po zburzeniu Troi do wędrówek Zaporożców po zburzeniu Siczy Zaporoskiej przez Katarzynę. Wykorzystując znany schemat fabuły Wergiliusza, Kotlarewski w swojej Eneidzie (1798 r.) sięgnął do źródeł, historii, języka i obyczajów własnego narodu, tworząc dzieło wyzwalające siłę duchową, drzemiącą w owych zabytkach i budzące wyobraźnię historyczną. Ból i cierpienia Eneasza związane z losem ojczyzny głęboko poruszyły Kotlarewskiego; wszak Eneasz wiedział, że poprzez cierpienia odzyska utraconą ojczyznę. Troja musi powstać, bo takie są wyroki bogów. Ta nadzieja podtrzymuje na duchu trojańskich wygnańców, którzy razem z Eneaszem będą założycielami nowego państwa rzymskiego.

To kluczowa przewodnia myśl ukraińskiej Eneidy i zarazem przesłanie wskazujące kierunek przemian i orientację kulturowo-cywilizacyjną dla współczesnego Kotlarewskiemu środowiska ukraińskich autonomistów, podejmujących działania na rzecz autonomii Ukrainy, pobudzając jednocześnie impulsy do jej ustrojowej modernizacji. Aby uwydatnić powyższy problem - nota bene pomijany przez ukrainistów - pragnę jeszcze raz przypomnieć, iż mit założycielski Europy to właśnie opowieść o Eneaszu, który uciekł z płonącej Troi i dotarł aż do Italii.

Ten świadomy wybór Kotlarewskiego nadał ruchowi autonomistów konkretny kierunek i wymiar działania. Sam autor zaproponował niebanalny pomysł, aby z zaporoskich wygnańców nad Donem i za Dunajem utworzyć podczas kampanii napoleońskiej pułki Kozaków Siczowych, nawiązując tym 
samym do militarnych tradycji Kozaczyzny. Zresztą kampania napoleońska była dla pokolenia autonomistów niebywałym doświadczeniem ${ }^{14}$, wszak na dużą skalę miało ono kontakt z Zachodem, jego ustrojowymi porewolucyjnymi rozwiązaniami, cywilizacją, życiem. Warto zauważyć, iż na poglądy tego pokolenia inteligencji ukraińskiej złożyły się wpływy ideowe i kulturowe zachodniego oświecenia i duch preromantyzmu, tradycja lóż masońskich oraz nowe zjawiska i procesy, wywołujące ferment we wszystkich krajach Europy.

Tak rodziły się początki nowożytnej ukraińskiej orientacji okcydentalistycznej przełomu XVIII-XIX wieku. Uwaga inteligencji skupiła się na wprowadzaniu przemian ustrojowo-społecznych, organizacji szkolnictwa, w tym zawodowego, oraz utworzeniu uniwersytetu, najpierw w Charkowie, z udziałem profesorów z Niemiec, a następnie w Kijowie. W tych działaniach widziano drogę i czynnik sprawczy przyszłych zmian. Miały też one wpłynąć na kształtowanie się jednostkowej i zbiorowej świadomości narodu, jego społecznej aktywności.

Nie przypadkiem więc ze ścisłego grona ukraińskich autonomistów wyszło wówczas anonimowo - co zrozumiałe z uwagi na szalejącą carską cenzurę - wspomniane kapitalne dzieło z przełomu XVIII i XIX w. pt. Historia Rusów ${ }^{15}$. Ten historiozoficzny traktat znakomicie wpisuje się $\mathrm{w}$ ówczesne dążenia Ukraińców, przedstawiając intrygująco i barwnie dzieje Ukrainy, jej heroiczne walki, kulturę i tradycje demokratyczne. Wzorując się na Liwiuszu i Tacycie, anonimowy autor wkładał w usta bohaterów i postaci historycznych piękne patriotyczne przemówienia, co budziło wyobraźnię historyczną i motywowało do działania.

Historia Rusów jest kontynuacją latopisarstwa kozackiego, ale stanowi jednocześnie jej piękne zwieńczenie. Wszelako w odróżnieniu od dzieł Samowidźcy, Hrabianki czy Wełyczki anonimowy autor w swojej ocenie dziejów dał zdecydowany wyraz niezgody i sprzeciwu Ukraińców wobec aktów likwidacyjnych i restrykcji podjętych najpierw przez Piotra I (przeciwko któremu wystapił hetman Iwan Mazepa wraz z swoim szwedzkim sojusznikiem Karolem XII), zwłaszcza zaś przez Katarzynę II, dotyczących - przypomnijmy - likwidacji Hetmańszczyzny (1764), Siczy Zaporoskiej (1775) i zaprowadzenia poddaństwa (1783). To były śmiertelne ciosy dla losów Ukrainy, dlatego też autor podkreśla z całą mocą, że lepiej i godniej „trwać w nieustannych walkach o wolność, aniżeli nakładać na siebie kajdany poddaństwa i niewoli”16.

\footnotetext{
14 W niektórych miastach Ukrainy Napoleon był entuzjastycznie witany, np. w Połtawie biskup Warłaam Szyszacki z wiernymi witał go chlebem i solą. Historyk I. Borszczak podaje, że na wzór Księstwa Warszawskiego Napoleon miał zamiar utworzyć odrębne Księstwo - Ukrainidę, zob. I. Борщак, Наполеон і Україна, Львів 1938.

15 Zob. S. Kozak, Preromantyzm ukraiński, op. cit. (cz. III i IV) oraz por. tenże, U źródet..., op. cit., rozdz. III i IV, gdzie przywoływana jest obszerna literatura naukowa.

16 Ibidem, s. 78 [Historia Rusów, s. 136].
} 
Filozofując na tematy historyczne i polityczne oraz wychodząc $\mathrm{z}$ ducha Rozprawy o nierówności Rousseau, Ducha praw Monteskiusza oraz Myśli o filozofii dziejów Herdera, autor Historii Rusów nieustannie podkreśla, że ujarzmiać inny naród jest rzeczą haniebną, narzucać mu władzę - niemoralną. Pada zatem pytanie: ,skąd się to bierze, że ty monarcho [mowa o Piotrze I] stawiasz siebie ponad obowiązującym prawem, niszczysz nas swoją nieograniczoną władzą i trzymasz $\mathrm{w}$ więzieniach, zgarnąwszy majątek do swojego skarbca? Wszak winy, którymi nas obciążasz, to tylko nasz obowiązek, święta powinność, szanowana przez wszystkie narody, a nie przestępstwo podlegające osądowi”"17.

Powyższe uwagi raz jeszcze przekonują, że ukraińska nowożytna myśl okcydentalistyczna kształtowała się w opozycji do wschodniego, tj. rosyjskiego despotyzmu, zaś żywy jeszcze duch wolności Kozaczyzny znalazł walne wsparcie we współczesnych procesach społeczno-politycznych oraz przełomowych rewolucyjnych wydarzeniach we Francji, Europie i Ameryce.

$\mathrm{W}$ tym samym kontekście łatwiej zrozumieć, dlaczego w środowisku ukraińskich autonomistów, starszyzny i bractwa kozackiego oraz inteligencji widzimy narastającego „ducha wyraźnej opozycji” przeciwko nieograniczonej samowoli carskiej i naporowi obskurantyzmu, będących reakcją „na naruszenie praw i wolności Ukrainy". Zgodnie z nowym duchem czasu chętnie sięgano więc do budzących wyobraźnię historyczną latopisów kozackich i epiki bohaterskiej ukazujących barwnie heroiczne dzieje, przywołujących obrazy powstań i buntów oraz ich bohaterów. Oto jeden z nich w ostrych słowach zwraca się do cara: ,ujarzmiać naród ukraiński lub innemu darować nikt nie ma prawa, w przeciwnym bowiem przypadku on gotów jest znowu mężnie bronić się do końca i raczej zgodzi się umrzeć z orężem w ręku, niż cierpieć w haniebnym jarzmie"18.

Ciekawe, że na przykład obok Sahajdacznego, Chmielnickiego czy Połubotka (wbrew zakazom i rzuconej anatemie) duże zainteresowanie budził hetman Iwan Mazepa, czemu zapewne sprzyjało nagłośnienie jego postaci oraz działalności wobec europejskiej opinii publicznej przez Woltera, Byrona, Gotshala i innych. Wszelako decydującym czynnikiem był fakt, że to właśnie hetman Iwan Mazepa w sojuszu z królem szwedzkim Karolem XII wystąpił zbrojnie przeciwko „wschodniemu despocie” Piotrowi I, co - jak wiadomo zakończyło się sromotną klęską, acz niewątpliwie przyniosło Ukrainie spory rozgłos w Europie.

Do nagłośnienia sprawy przez wybitne postacie Europy przyczynił się także następca Mazepy, hetman Pyłyp Orłyk, który w swoim francuskojęzycznym Manifeście do państw Europy oraz traktacie, napisanym także po

17 Ibid., s. 111 [Historia Rusów, s. 308].

18 Ibidem, s. 223. 
francusku i zatytułowanym Wywód praw Ukrainy, przedstawił obraz „,narodu kozackiego", formowanie się jego demokratycznych tradycji, walki o wolność, a także podstaw państwowości Hetmańszczyzny; zwrócił jednocześnie uwagę opinii europejskiej na zagrożenie ze strony despotyzmu Moskwy:

Ci, którzy dbają o interes całej Europy i każdego państwa z osobna, z łatwością zrozumieją, jakie zagrożenia dla wolności Europy płyną od tak agresywnego [jak Rosja] państwa. Dobrze oni wiedzą o tym z historii, ale głównie dzięki wielkiemu doświadczeniu i głębokiej mądrości, co jest dobre dla ich państwa i dla interesów Europy ${ }^{19}$.

Artykułując te zagrożenia, hetman Orłyk jednocześnie podkreślił, iż dla zapewnienia pokoju w Europie jest nieodzowna restytucja Ukrainy. Tę ideę starał się on upowszechniać będąc już na emigracji, zaś jego dyplomaci wykazywali w tym względzie wiele umiejętności, docierając na dwory książęce i królewskie Europy. Największe sukcesy osiągnął na tym polu starszy syn hetmana Hryhorij Orłyk, który dzięki małżeństwu z hrabiną Dentevil, oprócz uzyskania tytułu hrabiowskiego został mianowany przez króla marszałkiem polnym Francji, jednocześnie pełniąc specjalną misję dyplomatyczną dotycząca spraw Europy Wschodniej. Nie przypadkiem więc proponuje on rządom Francji i Szwecji utworzenie antyrosyjskiej koalicji z udziałem również Prus, Polski, Turcji i Krymu, która to koalicja byłaby w stanie powstrzymać ekspansję Rosji, przywrócić Ukrainie wolność i zapewnić pokój w Europie ${ }^{20}$.

W zarysie historii zjawisk, procesów i faktów składających się na tytułowe zagadnienie „Ukraina między Wschodem a Zachodem” zasygnalizowana wyżej koncepcja należy do zdecydowanie proeuropejskiej, najbardziej nowoczesnej, znacznie wyprzedzającej swoją epokę. Ta tkwiąca korzeniami głęboko w dziejach Ukrainy okcydentalistyczna orientacja padła na przyjazny grunt czasów nowożytnych, stanowiąc genezę odrodzeńczego ruchu narodowego oraz późniejszych przemian, realizowanych przez kręgi autonomistów, masonów, tj. pokolenie autora ukraińskiej Eneidy - Kotlarewskiego - i anonimowego autora Historii Rusów, a także młodej inteligencji zrzeszającej się w towarzystwach oświatowych, uniwersyteckich i konspiracyjnych stowarzyszeniach o zdecydowanym antymonarchicznym nastawieniu i programie demokratycznych reform ${ }^{21}$.

\footnotetext{
19 Вивід прав України. Документи і матеріали до історії украӥнської політичної думки. У поряд, і вступна стаття Б. К равціва, Нью-Йорк 1964, s. 94.

20 Zob. I. Борщак, Великий мазепинеиъ - Григор Орлик, Львів 1932; E. Borschak, Hryhor Orlyk-France's Cossack, Général, Toronto 1956.

${ }_{21}$ Zob. Я. Грицак, Нариси історії України: формування модерної української нації XIXXX cm., Київ 1996 i por. S. Kozak, Preromantyzm ukraiński, op. cit. (cz. III-VI).
} 
W tym procesie kształtującej się - w opozycji do zagrożenia „rosyjskością” - ukraińskiej „europejskości”, począwszy od Mohyły, Prokopowicza, Wyhowskiego, Połubotka, Mazepy, ojca i syna Orłyków, braci Poletyków, do interesującej nas generacji przełomu XVIII i XIX wieku, należy także szukać źródeł integrujących narodowość ukraińską, czynników kształtujących jej świadomość, tempo procesów narodotwórczych, przesłanek formowania się podstaw nowoczesnego egalitaryzmu, ogólnospołecznych postaw i umocnienia patriotycznych uczuć, nadających nowy sens pojęciom „naród” i „ojczyzna", uświadamianych w kontekście zdobyczy czasów nowożytnych, tj. Wielkiej Rewolucji Francuskiej oraz Rewolucji i Konstytucji Amerykańskiej.

Pogłosy „ducha nowożytnej epoki” przytaczane w dotychczasowych rozważaniach, wychodzące z Połtawy, Obuchiwki czy Charkowa, najbardziej donośnie zabrzmiały w Kijowie w dokumentach konspiracyjnego Bractwa Cyryla i Metodego, w jego odezwach, a przede wszystkim w Ksiegach bytu narodu ukraińskiego autorstwa historyka, publicysty i pisarza Mykoły Kostomarowa ${ }^{22}$. Sytuując ten młodoukraiński ruch w nurcie współczesnych prądów europejskich, a więc idei Mazziniego i jego „Młodej Europy”, socjalizmu utopijnego Saint- Simona i Lammenaisa, pragnę podkreślić, iż zarówno Księgi bytu Kostomarowa, jak i traktat emigranta Hipolita Terleckiego Stowo Rusina znakomicie wpisują się w toczącą się wówczas w Europie w gronie twórców „szczęśliwych światów” dyskusję o wolności, równości i sprawiedliwości społecznej, o nadziei na „nadejście nowej epoki chrystianizacji życia politycznego i społecznego, która ma zbawić ludzkość i która ma zainaugurować taką epokę w historii świata, w której zasady chrześcijańskie będą obowiązywały w życiu społecznym i w polityce, zaś w świecie zapanuje wolność i sprawiedliwość" 23 .

Wskazując na ukraiński udział w trendach i kulturze europejskiej, pragnę jednocześnie uwydatnić, iż nie jest to - jak się często postrzega - wkład oceniany w kategoriach kolorytu lokalnego, lecz wyraz świadomości europejskiej, szerzej - zachodniej. Przytaczane w niniejszych rozważaniach przykłady takiej świadomości chciałbym zwieńczyć słowami najwybitniejszego cyrylometodyjczyka, proroka ukraińskiego odrodzenia narodowego, Tarasa Szewczenki:

Німії, подлії раби,

Підніжки, царськії лакеї Капрала п’яного! Не вам,

Не вам, в мережаній лівреї Донощики і фарисеї,

За правду пресвятую стать

I за свободу. Розпинать,

22 S. Kozak, Ukrainscy spiskowcy i mesjaniści. Bractwo Cyryla i Metodego, Warszawa 1990.

23 С. Козак, Християнство - романтичний месіанізм - сучасність, Київ 2011, s. 239. 
А не любить ви вчились брата!

О роде суєтний, проклятий,

Коли ти видохнеш? Коли Ми діждемося Вашінгтона

3 новим і праведним законом?

А діждемося - таки колись! ${ }^{24}$.

Fundamenty historiozofii Tarasa Szewczenki są nader czytelne, są to bowiem wartości humanistyczne człowieka, dla którego prawdy boskie i prawdy historyczne są wartościami stałymi, wiecznie żywymi, stanowiącymi o porządku rzeczy i świata. Profetyczne słowa poety przywołujące imię pierwszego prezydenta porewolucyjnej demokratycznej Ameryki Jerzego Waszyngtona i słynną Konstytucję to stanowcze zwrócenie się ku Zachodowi, ku jego wielkiej sprawczej i dziejowej rewolucyjnej sile, która miałaby podnieść Ukraińców z kolan, powstrzymać jego dalszą asymilację, degradację, zapalić płomień wolności i przynieść niepodległość.

Tym tropem można podążać dalej, ale to już osobny temat. Na koniec warto podkreślić, iż omawiany problem „Ukraina między Wschodem a Zachodem" dał możliwość spojrzenia na Ukrainę i jej dzieje z nieco odmiennej perspektywy. Bardzo pouczające było to, że Ukraińcy, będąc przez wieki przedmiotem wielorakiej, bezpardonowej i wielostronnej presji z zewnątrz, zachowali swoją etniczną, językową i kulturową odrębność, że mimo różnorakich zabiegów, nie wyłączając barbarzyńskich, nie dali się zasymilować przez Carskie Imperium.

Tu dotykamy niesłychanie istotnej kwestii, a mianowicie, że to właśnie owe zagrożenia i niepewny los Ukraińców w dużym stopniu spełnił rolę „dźwigni” świadomości narodowej, przyczyniając się do ich sformowania się w nowożytną wspólnotę narodową. I wreszcie, geocywilizacyjne położenie między światem kultury i cywilizacji Wschodu i Zachodu sprawiło, że świadomość europejska była w większym lub mniejszym nasileniu zawsze na Ukrainie obecna, stanowiąc siłę w kształtowaniu się tożsamości narodowej i europejskiej Ukraińców.

Podsumowując, pragnę w zakończeniu zwrócić uwagę na to, co dzieje się aktualnie w Ukrainie, jakie procesy, tendencje i przemiany kulturowe, cywilizacyjne i geopolityczne zajmują umysły i działania światłych Ukraińców oraz jakich wyborów dokonuje Ukraina świadoma dziejowej misji, jaką rolę ma odegrać w tym przełomowym dlań historycznym okresie.

24 Т. Шевченко, Повне зібрання творів у шести томах, т. II, Київ 1963, s. 296. 


\section{BIBLIOGRAFIA}

Borŝak Ìllâ. 1932. Velikij mazepinec' - Grigor Orlik. L'vìv: Vidavniča kooperativa “Červona kalina” [Борщак Ілля. 1932. Великий мазепинеиь - Григор Орлик. Львів: Видавнича кооператива "Червона калина"].

Borŝak İllâ. 1938. Napoleon ì Ukraïna. L'vìv: Z drukarnì Vidavičoï Spìlki “Dìlo" [Борщак Ілля. 1938. Наполеон і Україна. Львів: 3 друкарні Видавичої Спілки “Діло”].

Borschak Elie. 1956. Hryhor Orlyk - France’s Cossack, Général. Toronto: Burns \& MacEachern.

Chynczewska-Hennel Teresa. 1995. Łacina na Zaporożu. W: Konteksty: Między Slavia latina a Slavia orthodoxa. Red. Głębicka E. J., Axer J. Warszawa: Ośrodek Badań nad Tradycją Antyczną w Polsce i w Europie Środkowo-Wschodniej.

Davies Norman. 2007. Europa między Wschodem a Zachodem. Kraków: Wydawnictwo Znak. Ševčenko İgor. 2001. Ukraïna miž Shodom ì Zahodom. L'vìv: İnstitut İstorï̈ Cerkvi L'vìvs'koï Bogoslovs'koï Akademiї [Шевченко Ігор. 2001. Україна між Сходом $i$ Заходом. Львів: Інститут Історії Церкви Львівської Богословської Академіï].

Głębicka Ewa Jolanta, Axer Jerzy [Red.]. 1995. Konteksty: między Slavia Latina i Slavia Orthodoxa. Warszawa: Ośrodek Badań nad Tradycją Antyczną w Polsce i w Europie Środkowo-Wschodniej.

Gricak Âroslav. 1996. Narisi istorï Ukraïni: formuvannâ modernoï ukrä̈ns'koï nacï XIXXX st., Kiïv: Geneza [Грицак Ярослав. 1996. Нариси історії України: формування модерної української нації XIX-XX ст., Київ: Генеза].

Jakowenko Natalia. 1995. Niespodzianki ukraińskiej historii przedstawionej po łacinie. W: Konteksty: Między Slavia latina a Slavia orthodoxa. Red. Głębicka E. J., Axer J. Warszawa: Ośrodek Badań nad Tradycją Antyczną w Polsce i w Europie ŚrodkowoWschodniej: 45-54.

Kozac'kì pisni. 1969. Kiїv: Muzična Ukraïna [Козацькi niснi. 1969. Київ: Музична Україна].

Kozak Stefan. 1978. U źródeł romantyzmu i nowożytnej myśli społecznej na Ukrainie. Wrocław: Ossolineum.

Kozak Stefan. 1990. Ukraińscy spiskowcy i mesjaniści. Bractwo Cyryla i Metodego. Warszawa: Pax.

Kozak Stefan. 2003. Preromantyzm ukraiński. Warszawa: Katedra Filologii Ukraińskiej Uniwersytetu Warszawskiego.

Kozak Stefan. 2011. Hristiânstvo - romantičnij mesìanìzm - sučasnìst'. Kiïv: İnstitut literaturi ìm. T.G. Ševčenka NAN Ukraïni [Козак Стефан. 2011. Християнство романтичниймесіанізм-сучасність. Київ: Інститут літератури ім. Т.Г. Шевченка НАН України].

Kravcìv Bogdan. 1964. Vivìd prav Ukraïni. Dokumenti ì materìali do ìstoriï ukraïns'koï polìtičnoï dumki. N'û-Jork: Prolog [Кравців Богдан. 1964. Вивід прав України. Документи і матеріали до історії української політичної думки. Нью-Йорк: Пролог].

Nud'ga Grigorì Upor. 1969. Dumi: Poetičnij epos Ukraïni. Kï̀v: Radâns'kij pis'mennik [Нудьга Григорій Упор. 1969. Думи: Поетичний епос Украӥни. Київ: Радянський письменник].

Ranińska Agnieszka [Red.]. 1995. Tradycje antyczne w kulturze europejskiej-perspektywa polska. Warszawa: OBTA.

Ševčenko I. 1996. Ukraina między Wschodem a Zachodem. Warszawa: OBTA. 
Ševčenko Taras. 1963. Povne zibrannâ tvorìv u šesti tomah. T. II. Kiïv: Vidavnictvo Akademiï nauk URSR [Шевченко Тарас. 1963. Повне зібрання творів у шести mомах. Т. II. Київ: Видавництво Академії наук УРСР].

Wilson Andrew. 2002. Ukraińcy. Warszawa: Świat Książki.

\section{GLOSA W KWESTII UKRAINA MIĘDZY WSCHODEM A ZACHODEM}

Streszczenie: Autor pracy wychodzi od znanej i niemal oczywistej tezy o usytuowaniu Ukrainy pomiędzy bizantyńskim Wschodem a łacińsko-europejskim Zachodem i bierze pod uwagę wiele aspektów uzasadniających trafność tego twierdzenia: geograficzny, polityczny, historyczny, religijny, kulturowy, przy czym ukazuje, że każdy z nich jest wielorako powiązany z pozostałymi. Następnie dokonuje syntetycznego przeglądu faktów historycznych, kulturowych, ukraińskiego piśmiennictwa polityczno-ideowego, utworów literackich znakomitych twórców ukraińskich oraz anonimowych kozackich pieśni i dum pod kątem obecnej w nich myśli okcydentalistycznej, świadczącej o świadomym przyjmowaniu i rozwijaniu nowoczesnych, europejskich myśli: politycznej, wolnościowej i demokratycznej, przez myślicieli ukraińskich harmonijnie łączonych z cenionymi przez nich wartościami chrześcijańskimi. Celem przedstawionej syntezy jest charakterystyka nurtu prozachodnioeuropejskiego, ukazanie jego źródeł oraz rozwoju od czasów podległości Ukrainy wobec carskiej Rosji (po Ugodzie Perejasławskiej), w końcu funkcji, jaką pełnił: oporu wobec imperialnej, absolutystycznej i rusyfikacyjnej polityki dynastii Romanowów, także krystalizacji narodowej świadomości Ukraińców oraz ich dążeń wolnościowych.

Słowa klucze: Ukraina, bizantyjski Wschód, łacińsko-europejski Zachód, okcydentalizm, dążenia wolnościowe.

\section{ДО ПИТАННЯ УКРАЇНА МІЖ СХОДОМ І ЗАХОДОМ}

Анотація: Автор роботи виходить із відомої тези про розташування України між Візантійським Сходом та Латиноєвропейським Заходом, і враховує багато аспектів, які обгрунтовують точність цього твердження: географічний, політичний, історичний, релігійний та культурний, і показує, що кожен з них багато в чому пов'язаний з іншими. Потім він дає синтетичний огляд історико-культурних фактів, українських політичних та ідеологічних творів, літературних творів видатних українських авторів та анонімних козацьких пісень і дум з точки зору присутньої в них окциденталістської думки, демонструючи свідоме прийняття та розвиток сучасної європейської думки: політична, ліберальна та демократична думка, в українських мислителів гармонійно асоціюється з християнськиси цінностями, які вони плекають. Метою представленого синтезу є охарактеризувати прозахідноєвропейську тенденцію, показати ії витоки та розвиток від часів підпорядкування України царській Росії (після Переяславської угоди), нарешті, яку функцію вона виконувала: опір імперії та абсолютистській і русифікаторській політиці династії Романових, а також кристалізація національної свідомості українців та їх прагнення до волі.

Ключові слова: Україна, візантійський Схід, латиноєвропейський захід, окциденталізм, свободи. 